\title{
University Support, Teaching Competencies and Entrepreneurial Competencies in Software Engineering and Graphic Design Students
}

\author{
https://doi.org/10.3991/ijet.v16i02.17327 \\ Oswaldo Alberto Madrid Moreno, Marco Alberto Núñez Ramírez ${ }^{(凶)}$ \\ Instituto Tecnológico de Sonora, Sonora, Mexico \\ marco.nunezeitson.edu.mx
}

\begin{abstract}
The objective of this research was to evaluate how university support and teaching entrepreneurial competencies affect students' entrepreneurial competencies. As an empirical test, a sample of 201 software engineering and graphic design students from a university in Northwest Mexico was taken, where it was possible to corroborate three hypotheses. The results suggest that entrepreneurial competencies are influenced by external aspects, where the university can be understood as an open system, but also, as a part of a wider system within the triple helix. This shows that the joint work between the contextual and individual part can benefit the generation of innovation and development for society, especially in a country where there is a lack of $R \& D$, although the practice of entrepreneurship is high. As a result, the university can play a relevant role when developing entrepreneurial competencies to train students to become entrepreneurs through innovation and technology.
\end{abstract}

Keywords - Entrepreneurial competencies, entrepreneurial university, university support, teaching competencies.

\section{Introduction}

Entrepreneurship and technology are two aspects that have gone hand in hand. From a theoretical approach, technology has played a relevant role in the understanding of entrepreneurial education. For example, bibliometrics show that technology stands out among the main topics in the understanding of entrepreneurial education (e.g. Fellnhofer [1]; Kakouris and Georgiadis [2]), academic entrepreneurship (e.g. Skute [3]), and the literature on university-industry collaborations (e.g. Skute et al. [4]). Furthermore, an example of this is that both aspects - technology and entrepreneurship - were already considered jointly when approaching the case of innovation since the 1940s during the Schumpeter's work [5], author who is considered one of the precursors of the study of entrepreneurship; as well as the Drucker's management thought [6]. It is also important to note that articles relating entrepreneurship to technological aspects have been frequently published in recent years [7-8]. 
An emerging paradigm within this research field is the entrepreneurial university, which by combining teaching and research, aims to promote technological innovation [9]; additionally, it favors economic development, through its participation in the socalled triple helix (academy, industry and government relations) [10]. Under this perspective, the development of entrepreneurs plays a transcendental role, especially in certain regions of the world, as is the case of Latin America, where there are problems to be undertaken through technology. This is in spite of the fact that this region has the highest levels of TEA (Total Early-stage entrepreneurial Activity) since Mexico stands out by placing 17th in the world ranking, according to the Global Entrepreneurship Monitor [11]; however, it is important to point out that within the main weaknesses of this country, is the lack of R\&D. For this reason, entrepreneurship in this location has been characterized by a lack of competitiveness [12-13] with technology and innovation being its main weaknesses [14].

This phenomenon can be understood from the contextual and individual part. On the one hand, from the first approach, the university is an important part of the triple helix [10], and can provide alternatives to counteract this problem; nevertheless, the university's participation in entrepreneurial development has been limited. An example of this, is that it has been oriented mainly towards the creation of incubators for external users [15]; in addition, certain weaknesses stand out, such as the lack of promotion of an entrepreneurial culture among students, the low use of science and technology platforms for innovation, and the development of entrepreneurial human capital [16].

From a structural and contextual point of view, it is important to understand that the university is a complex system [17], which is integrated by different elements (e.g. authorities, administrators, staff, researchers, professors and students) and aspects that integrate the university context, which can favor entrepreneurship [18]. In the case of student entrepreneurship, this can be explained through the influence of University Support [19] and Teaching Competencies [20-21]; the latter, considering that entrepreneurship can be taught [22].

On the other hand, from the individual point of view, it is necessary to understand that an entrepreneur is defined by what he or she does: create a business [23-24]; likewise, the university plays a very important role in the individual part of the entrepreneur $[25,9]$, where the formation of entrepreneurial skills and competencies stand out as essential to guarantee success [21, 26-28].

Finally, from the contextual point of view, it is imperative to consider that both the university and the scholar must develop different competencies in students [29], where entrepreneurial competences play an important role in generating value for society [21]; therefore, the following research question arises: how do university support and teaching competencies affect student's entrepreneurial competencies?

As empirical evidence, the importance of developing entrepreneurial competencies in engineering students to promote innovation in Mexico is highlighted. This country has high levels of entrepreneurial activity worldwide, but also presents low levels in the area of $R \& D$ [11, 14]; moreover, it is not entirely clear how universities are influencing the education of future entrepreneurs in this country because, even though empirical evidence has increased (e.g. Gerrero, Urbano and Gajon [30]; Guerrero, Urbano, Cunningham and Gajon [31]; Guerrero, Urbano and Gajon [32]), more research is needed, 
especially among the engineering students. Engineering students could contribute to transform Mexico from a country oriented towards service entrepreneurship to one based on technology and innovation.

As a result, it was decided to study a sample of students from a university in northwestern Mexico. In order to contribute to regional development, this university has sought to implement a cross-cutting entrepreneurial education within its curriculum over the past few years [33-34]. Due to its geographic location, this institution serves over 17,000 undergraduate students [35], mostly from three states: Sonora, Sinaloa and Chihuahua. It is highlighted that its mission is focused on developing entrepreneurial competencies in its students [36].

The structure of the following document is articulated in the following way: in the first section, the theoretical framework of the study variables is presented (i.e. university context, as well as the entrepreneurial competencies of the professor and the student), to later formulate the hypotheses, through which a methodological design is developed. Finally, the results and conclusions are shown.

\section{Theoretical Framework and Hypotheses}

When looking more deeply into the theoretical orientations on the subject of entrepreneurship, it can be seen that there are two main areas. The first one is about the internal aspects of the person that allude to the individual factors (e.g. McClelland [37]; Islam [25]), where competencies play an important role (e.g. Arafeh [26]; Robles and Zárraga-Rodríguez [27]; Peltonen [21]; Rasmuseen and Wright [18]); on the other hand, there are external aspects to the individual, also called environmental or contextual factors (e.g. Schumpeter [5]; Clarysse et al. [38]), where the university stands out [9-10], and the influence of the professor (e.g. Heinone and Hytti [20]; Peltonen [21]; Heinonen, and Akola [39]). These aspects constitute the study variables, which are described below.

\subsection{Student's entrepreneurial competencies}

Broadly speaking, the entrepreneurial competencies promote the development of capacities to create a company, the identification and creation of business opportunities, as well as the search for economic or social benefits, innovation, individual or collective work, and the combination of resources and talents [40]. According to Duarte and Ruiz [41], they also identify different aspects, such as: creativity, flexibility, risk, the need for achievement, discipline and dynamism. In this sense, these skills need to be understood under the competency model, which Tinoco [42] groups them into five dimensions.

A competence is defined as a set of skills that a person has developed to achieve a specific objective [43]. In fact, an entrepreneurial competence is formed by certain skills that allow an individual to create a successful business. Although, there is no fully accepted taxonomy of what these skills should be, some authors classify them into technical, business management, thinking and personal (e.g. Hatthakijphong and Ting [44]). 
As for the latter, there are different models that explain them (e.g. McClelland [37]; Arafeh [26]; Robles and Zárraga-Rodríguez [27]; D'Este et al. [45]). For this research, and considering that it is a Latin American study, we took the model proposed by Tinoco [42], whose taxonomy is based on entrepreneurial competencies that have empirical evidence to support them: self-knowledge (e.g. Fernandez and Miñarro [46]), achievement motivation (e.g. Duarte and Ruiz [41]; McClelland [37]), vision (e.g. Chihsiang [47]; Carrera et al. [48]), planning (e.g. Chang and Chen [49]), and persuasion (e.g. Robles and Zárraga-Rodríguez [27]; Zampetakisa et al. [50]). It is important to note that some of these variables are within the models described.

The development of self-knowledge goes back to classical Greek philosophy, especially to Socrates [51], which allows the individual to have self-control in order to achieve personal goals [52]. In this sense, self-knowledge includes internal states and positive resources, which serve as emotional support and encourage entrepreneurial activity [46]. On the other hand, achievement motivation within entrepreneurial activity dates back to studies by McClelland [37], who found that self-employed people were attracted to achieving complex goals, especially generating their own business; an aspect that has been addressed by empirical studies (e.g. Duarte and Ruiz [41]). Another competence that defines the entrepreneur is vision, that is the ability to anticipate the future [48]. Planning, an aspect present in management since Fayol's work [53], allows the development of strategies for the success of a business [49]. Finally, persuasion permits the entrepreneur to influence others [50].

\subsection{University entrepreneurial support}

In recent years, the model of entrepreneurial university has gained importance [9], which aims to contribute the innovation and economic development [10]. For this reason, entrepreneurial universities play an important role through the production and dissemination of knowledge [30], as well as the generation of business incubators [31], which in general terms, they can impact on the development of future entrepreneurs. This has led to the emergence of different studies, which have put both scholars and students as the object of study. As for academics, Rasmussen and Jarl [54] found that the university context impacts on the entrepreneurial process, especially in the construction of capacities that facilitate entrepreneurship through a longitudinal study; in contrast, Rasmuseen and Wright [18] addressed the literature that explained academic entrepreneurship and entrepreneurial competencies. In the Latin American context, Fischer et al. [55], studied faculty members from different Brazilian universities, where they found that many aspects of the university context do not promote academic entrepreneurship, which has prevented the adaptation of strategies that encourage this aspect within the region.

Although it is true that academic entrepreneurship can have an impact on the development of entrepreneurs, more studies are needed to be oriented towards students, especially in countries like Mexico, where university education is playing a very important role in the entrepreneurial ecosystem; however, there are aspects to be developed and improved such as association with other actors (e.g. industry), and the improvement of incubators [15]. It is important to note that the entrepreneurial university 
is something recent in Mexico. It is true that most universities have entrepreneurial programs and generate a large number of entrepreneurial projects, many of which do not prosper and die due to lack of adequate follow-up [56]. Based on the above and in response to the research question, the following hypothesis is established:

$H_{1}=$ The greater the university support, the greater student's entrepreneurial competencies.

\subsection{Entrepreneurial teaching competencies}

Teaching activity needs changes in the objectives and expected results in order to bring universities towards the model of the entrepreneurial university. Changes are also required in their planning, teaching requirements and in the teaching-learning process, which must be closely linked to the business and professional environment. In the same way, graduates must be trained to be useful to society and companies in terms of their attitude and capacity for innovation and entrepreneurship, so they can impact and comply with their social responsibility to generate value in their regional economic environment.

Although, the study of entrepreneurial education has been increasing [1], the role of the professor has been little researched [20]. It is important to highlight that the professor, within the organizational structure of the entrepreneurial university, plays a relevant role in training entrepreneurs, but he or she must first develop certain competencies. Empirical evidence has shown that these competencies can be learned from professors (e.g. Peltonen [21]). In order to potentiate entrepreneurial teaching, a new way of thinking is required, as well as the promotion of new skills and behaviors [39], where both the professor and the student are involved.

With this in mind, it is important to consider that the influence of the professor on the student can be very broad, highlighting the teaching and behavior. From the first approach, the teacher's pedagogy should be oriented to encourage students to be part of an entrepreneurial process within the different disciplines they are studying, in order to provide the skills to generate a future business [20]. In the area of the teacher entrepreneurial behavioral, studies have found that this has an important influence on individuals, especially within the promotion of innovation (e.g. Adeyemo [57]), and the development of entrepreneurial competencies (e.g. Van Dam et al. [58]). Mexico has had problems in promoting innovative and technological entrepreneurship [11, 14], and that the studied university has modified its programs in recent years to orient them towards the promotion of entrepreneurship through a transversal program of entrepreneurial education [36] and where the professor should play a relevant role [33-34]. On account of this, the second hypothesis arises:

$\mathrm{H}_{2}=$ The greater the entrepreneurial teaching competencies, the greater student's entrepreneurial competencies.

Finally, taking up all of the above, and with the intention of understanding the promotion of entrepreneurship, it is necessary to consider that the university is a complex system [17], where professors are integrated [18]. As a result, it seeks to know if both aspects influence the development of entrepreneurial skills of students. Since there is 
not much empirical evidence on how both aspects influence the formation of entrepreneurial competencies, more studies are needed to explain how these external aspects university and teaching- can have a positive or negative impact on the individual, especially in aspects as personal as self-knowledge, achievement motivation, planning, vision and persuasion [42]. These are aspects that demonstrate that psychology plays a transcendental role in order to understand the entrepreneur [59]. Taking into account what defines an entrepreneur is his or her capacity to generate a new company [23], it is necessary to go further in order to improve the understanding of his or her actions, which will make it possible to develop an effective pedagogy that will have an impact on the training of entrepreneurs within the university; therefore, this is how the last hypothesis is developed:

$\mathrm{H}_{3}=$ The university support and entrepreneurial teaching competencies influence on student's entrepreneurial competencies.

\section{$3 \quad$ Research Methodology}

\subsection{Sampling}

A convenience sample of 201 graphic design $(n=149)$ and software engineering $(n$ $=52$ ) students from a university in Northwest Mexico was obtained. It should be noted that $23.4 \%$ of the sample were entrepreneurs (See Table 1).

Table 1. Sample Characterization

\begin{tabular}{|l|c|c|}
\hline \multicolumn{1}{|c|}{ Characteristics } & $\boldsymbol{n}$ & \% \\
\hline Gender & 105 & 52.2 \\
\hline Female & 96 & 47.8 \\
\hline Male & & 74.1 \\
\hline Educational Program & 149 & 25.9 \\
\hline Graphic Design & 52 & 19.9 \\
\hline Software Engineering & & 2.0 \\
\hline Semester & 40 & 11.9 \\
\hline First & 4 & 0.5 \\
\hline Second & 24 & 32.3 \\
\hline Third & 1 & 1.5 \\
\hline Fourth & 65 & 13.4 \\
\hline Fifth & 3 & 18.4 \\
\hline Sixth & 27 & 23.4 \\
\hline Seventh & 37 & 76.6 \\
\hline Eighth & & \\
\hline Are you currently an entrepreneur? & 47 & \\
\hline Yes & 154 & \\
\hline No & & \\
\hline
\end{tabular}




\subsection{Instrument}

The questionnaire was composed of three sections to measure students' perceptions. In the first one, the professor's competencies were evaluated in order to develop the entrepreneurial intention in the students. In this case, four items based on competency model for high education (knowing, being and doing) [29] were used, which were adapted to the topic of study (entrepreneurship). The items were the following: "My professors encourage me to create my own company"; "My professors train me to be an entrepreneur"; "The personality of my professors motivates me to create my own company"; "The experience of my professors motivates me to create my own company". Originally, the questionnaire was composed of seven items, but after the validity analysis (content, construct and convergence), it was modified. It should be noted that, as concerns content validity, a pilot test was applied. Regarding University support, an adaptation to Spanish of the Lüthje and Franke subscale [19] was used. Finally, for the student's entrepreneurial competencies, an adaptation of the indicators proposed by Tinoco [42] was used, which was composed of 12 items, and is integrated by five dimensions: self-knowledge ( 2 items), vision ( 2 items), achievement motivation (2 items), planning ( 3 items) and persuasion ( 3 items). The three sections were measured using the Likert-5 scale with values from 1 (strongly disagree) to 5 (strongly agree) (See Table 2).

\subsection{Validity and reliability}

To validate the measuring instruments, construct validity and convergent validity were measured. Regarding the entrepreneurial competencies, Principal component analysis with Varimax rotation was performed, where the five dimensions explained $72.73 \%$ of the variance. It has to be emphasized that favorable results were obtained for the Keiser-Meyer-Olkin test $(\mathrm{KMO}=.890 ; \mathrm{X} 2=.824 .45 ; \mathrm{df}=66 ; \mathrm{p}=.000)$. In addition, high values of the Average Variance Extracted (AVE) were found for all variable dimensions, which, according to Hair et al. [60], they should be greater than .50, showing that the indicators have favorable levels of construct and convergent validity. The construct validity refers to the degree that an instrument measures a dimension [43, 61], and is based on convergent validity, which it is understood as the degree the instrument measures a single feature of the variable [62]. The same happened in the case of University Support and Entrepreneurial Teaching Competencies, which are unidimensional variables. Regarding reliability, Composite Reliability was tested. The results were satisfactory because they were higher than .70 (See Table 2). 
Paper-University Support, Teaching Competencies and Entrepreneurial Competencies in Software...

Table 2. Validity and Reliability

\begin{tabular}{|l|c|c|c|}
\hline \multicolumn{1}{|c|}{ Variable } & Items & AVE & Composite Reliability \\
\hline Entrepreneurial Teaching Competencies & 4 & .670 & .889 \\
\hline University Support & 3 & .518 & .763 \\
\hline Self-knowledge & 2 & .552 & .702 \\
\hline Vision & 2 & .599 & .749 \\
\hline Achievement Motivation & 2 & .563 & .721 \\
\hline Planning & 3 & .572 & .800 \\
\hline Persuasion & 3 & .524 & .764 \\
\hline
\end{tabular}

\subsection{Research process}

After having obtained the approval of the authorities from a university in Northwest Mexico, the questionnaire was applied through self-administration. A total of 320 questionnaires were obtained; however, some of them that had missing data and others that reflected inconsistencies (e.g. social desirability) were eliminated. The data were analyzed using the Statistical Package for the Social Sciences (SPSS) version 21 software. As a way to test the study hypotheses, correlation and multiple regression were also performed. In the case of the latter, the Variance Inflation Factor (VIF) was analyzed to evaluate problems of collinearity, where values of less than 1.40 were obtained in all models, which, according to Hair et al. [60], is adequate since these values are less than 10.

\section{Results and Discussion}

The presentation of the results is based on structured assumptions. Firstly, with respect to $\mathrm{H}_{1}$ and $\mathrm{H}_{2}$ in Table 3, it can be seen that both Entrepreneurial Teaching Competencies and University Support are positively associated with the student's entrepreneurial competencies. The results of the correlation can be interpreted from different perspectives: a) the findings reflected that the contextual part has been positively and significantly associated with the individual part in the studied university; b) this is in line with empirical evidence that has been found that, in terms of entrepreneurship formation, the university has a relevant impact [9-10], as well as the behavior and teachings of the professor [20-21, 39]; c) this reflects the relevance to evaluate the third hypothesis. 
Table 3. Correlation of variables

\begin{tabular}{|l|c|c|c|c|c|c|c|}
\hline \multicolumn{1}{|c|}{ Variables } & $\mathbf{1}$ & $\mathbf{2}$ & $\mathbf{3}$ & $\mathbf{4}$ & $\mathbf{5}$ & $\mathbf{6}$ & $\mathbf{7}$ \\
\hline 1. Entrepreneurial teaching competencies & 1 & & & & & & \\
\hline 2. University Support & $.441^{* *}$ & 1 & & & & & \\
\hline 3. Self-knowledge & $.194^{* *}$ & .113 & 1 & & & & \\
\hline 4. Vision & $.322^{* *}$ & $.157^{*}$ & $.485^{* *}$ & 1 & & & \\
\hline 5. Achievement motivation & $.314^{* *}$ & $.195^{* *}$ & $.457^{* *}$ & $.641^{* *}$ & 1 & & \\
\hline 6. Planning & $.246^{* *}$ & $.194^{* *}$ & $.416^{* *}$ & $.517^{* *}$ & $.598^{* *}$ & 1 & \\
\hline 7. Persuasion & $.313^{* *}$ & .058 & $.367^{* *}$ & $.543^{* *}$ & $.544^{* *}$ & $.520^{* *}$ & 1 \\
\hline
\end{tabular}

** $p \leq 0.01$ (2-tailed); * $\mathrm{p} \leq 0,05$ (2-tailed)

For $\mathrm{H}_{3}$, five multiple regressions were performed. Three models and control variables were used (i.e., entrepreneur status and program) and had a significant impact on vision (Table 5). The results are reported in Tables 4 to 8 . With respect of the selfknowledge variable, it is understood as an internal state that allows to have a domain on itself [46], in order to achieve personal goals [52], and it was found that it was influenced only by University Support $\left(\beta=204 ; p \leq .05\right.$; Adjusted $\left.\mathrm{R}^{2}=3.4 \%\right)$. Considering that this competence is very important for the development of the human part of the entrepreneur, it could be significantly enhanced through the entrepreneurial behavior of the professor, and it can impact in a favorable way on the organizational structure and on the students [63]. Regarding the context, different academics have emphasized the need to promote self-knowledge in Mexican culture [64-67]. This seems to be another opportunity area for the university in this country.

Table 4. Linear Regression: Self-Knowledge as dependent variable

\begin{tabular}{|l|c|c|c|}
\hline \multicolumn{1}{|c|}{ Variables } & Model 1 & Model 2 & Model 3 \\
\hline Control Variables & & & \\
\hline Entrepreneur Status & $\begin{array}{c}-.95 \\
(.130)\end{array}$ & $\begin{array}{c}. .108 \\
(.131)\end{array}$ & $\begin{array}{c}-.115 \\
(.129)\end{array}$ \\
\hline Program & $\begin{array}{l}.036 \\
(.126)\end{array}$ & $\begin{array}{c}.020 \\
(.126)\end{array}$ & $\begin{array}{c}.080 \\
(.132)\end{array}$ \\
\hline Entrepreneurial Teaching Competencies & & .125 & $.027 *$ \\
& & $(.084)$ & $.095)$ \\
\hline University Support & & & $.204^{*}$ \\
& & $.083)$ \\
\hline $\mathrm{R}^{2}$ & .009 & .024 & .054 \\
\hline Adjusted $\mathrm{R}^{2}$ & -.001 & .009 & .034 \\
\hline$F$ & .875 & 3.029 & $6.202^{*}$ \\
\hline
\end{tabular}

$* * p<.01 ;$ (standard error)

Conversely, considering that the future entrepreneur requires cultivating the capacity to anticipate the future, Tables 5 and 7 show that both vision and planning were impacted by the two independent variables, with Adjusted R2 of $15.9 \%$ and 5.7\%, respectively. Then, the empirical evidence shows that such competencies, besides being an important part of the individual character of the entrepreneur, are also developed within the transversal program proposed by the studied university [33]. This reflects the fact that software engineering and design students feel supported, both by the university and 
professors, in developing their vision, that is, in anticipating the future [48], as well as in their planning capacity, which is indispensable for decision-making [49]. From a cultural approach, these aspects require attention, especially in Mexico, a country whose culture has been characterized by a short-term orientation [68].

Table 5. Linear Regression: Vision as dependent variable

\begin{tabular}{|c|c|c|c|}
\hline Variables & Model 1 & Model 2 & Model 3 \\
\hline \multicolumn{4}{|l|}{ Control Variables } \\
\hline Entrepreneur Status & $\begin{array}{c}-.234 * * * \\
(.118)\end{array}$ & $\begin{array}{c}-.257 * * * \\
(.116)\end{array}$ & $\begin{array}{c}-268 * * * \\
(.112)\end{array}$ \\
\hline Program & $\begin{array}{l}-.079 \\
(.114) \\
\end{array}$ & $\begin{array}{l}-.106 \\
(.112) \\
\end{array}$ & $\begin{array}{l}-.017 \\
(.115)\end{array}$ \\
\hline Entrepreneurial Teaching Competencies & & $\begin{array}{l}.209 * * \\
(.075)\end{array}$ & $\begin{array}{c}.065 \\
(.083) \\
\end{array}$ \\
\hline University Support & & & $\begin{array}{c}.299 * * * \\
(.072)\end{array}$ \\
\hline $\mathrm{R}^{2}$ & .069 & .111 & .176 \\
\hline Adjusted $\mathrm{R}^{2}$ & .060 & .098 & .159 \\
\hline$F$ & $7.379 * * *$ & $9.334 * *$ & $15.370 * * *$ \\
\hline
\end{tabular}

$* * p<.01 ;$ (standard error)

The achievement motivation, a variable with much empirical evidence within the entrepreneurial behavior (e.g. Duarte and Ruiz [41]), is understood as the need to meet difficult goals [37]. The results showed that independent variables impacted on this entrepreneurial competition. The interpretation of this result requires the understanding of contextual analysis due to the existence of contradictory data. From a cultural point of view [68], the Mexican culture has been characterized by a low tolerance for frustration, but this country has presented a high level of TEA [11], unlike first world countries. It may be possible to combine these perspectives to develop the training of entrepreneurs, when adapting the entrepreneurial university model to the reality of Mexico.

Table 6. Linear Regression: Achievement motivation as dependent variable

\begin{tabular}{|c|c|c|c|}
\hline Variables & Model 1 & Model 2 & Model 3 \\
\hline \multicolumn{4}{|l|}{ Control Variables } \\
\hline Entrepreneur Status & $\begin{array}{l}-.099 \\
(.117)\end{array}$ & $\begin{array}{l}-.124 \\
(.115)\end{array}$ & $\begin{array}{l}-.134 * \\
(.112)\end{array}$ \\
\hline Program & $\begin{array}{l}-.054 \\
(.113) \\
\end{array}$ & $\begin{array}{l}-.083 \\
(.111) \\
\end{array}$ & $\begin{array}{c}.00 \\
(.114) \\
\end{array}$ \\
\hline Entrepreneurial Teaching Competencies & & $\begin{array}{l}.225 * * \\
(.074) \\
\end{array}$ & $\begin{array}{c}.090 \\
(.083) \\
\end{array}$ \\
\hline Perceived university Support & & & $\begin{array}{c}.280 * * * \\
(.071)\end{array}$ \\
\hline $\mathrm{R}^{2}$ & .015 & .064 & .120 \\
\hline Adjusted $\mathrm{R}^{2}$ & .005 & .049 & .102 \\
\hline$F$ & 1.512 & $10.239 * *$ & $12.581 * * *$ \\
\hline
\end{tabular}

$* * p<.01 ;$ (standard error). 
Paper-University Support, Teaching Competencies and Entrepreneurial Competencies in Software...

Table 7. Linear Regression: Planning as dependent variable

\begin{tabular}{|l|c|c|c|}
\hline \multicolumn{1}{|c|}{ Variables } & Model 1 & Model 2 & Model 3 \\
\hline Control Variables & & & \\
\hline Entrepreneur Status & -.045 & -.069 & -.075 \\
& $(.127)$ & $(.125)$ & $-.124)$ \\
\hline Program & -.049 & -.077 & $(.127)$ \\
\hline Entrepreneurial teaching competencies & $(.123)$ & $(.121)$ & .124 \\
& & $\begin{array}{l}.215^{* *} \\
(.081)\end{array}$ \\
\hline University Support & & & $.1289^{*}$ \\
& & & $.079)$ \\
\hline $\mathrm{R}^{2}$ & .005 & .050 & .076 \\
\hline Adjusted $\mathrm{R}^{2}$ & -.005 & .036 & .057 \\
\hline$F$ & .543 & $9.260^{* *}$ & $5.479 *$ \\
\hline
\end{tabular}

$* * p<.01 ;$ (standard error)

Finally, Table 8 shows the findings that persuasion was only positively affected by the University Support $\left(\beta=363\right.$; Adjusted $\left.\mathrm{R}^{2}=9.7 \% ; F=21.006 ; p \leq .001\right)$. This reflects that there is still work to be done in terms of developing the entrepreneurial behavior of the professors, so they can develop their teaching competencies [29], and actively participate in the teaching-learning process to form entrepreneurs who generate value for society [21].

Table 8. Linear Regression: Persuasion as dependent variable

\begin{tabular}{|l|c|c|c|}
\hline \multicolumn{1}{|c|}{ Variables } & Model 1 & Model 2 & Model 3 \\
\hline Control Variables & & & \\
\hline Entrepreneur Status & -.073 & -.082 & $(.136)$ \\
& $(.136)$ & -.095 \\
& -.075 & $(.130)$ \\
\hline Program & $(.121)$ & $(.132)$ & $\begin{array}{c}.023 \\
(.133)\end{array}$ \\
\hline Entrepreneurial Teaching Competencies & & $\begin{array}{c}.082 \\
(.088)\end{array}$ & $\begin{array}{c}-.093 \\
(.096)\end{array}$ \\
\hline University Support & & & $.363^{* * *}$ \\
& & & $(.083)$ \\
\hline $\mathrm{R}^{2}$ & .013 & .020 & .115 \\
\hline Adjusted $\mathrm{R}^{2}$ & .003 & .005 & .097 \\
\hline$F$ & 1.335 & 1.307 & $21.006 * * *$ \\
\hline
\end{tabular}

$* * p<.01 ;$ (standard error)

\section{Conclusion}

It is true that concepts like entrepreneurship and technological development were already present since Schumpeter's creative destruction [5], and currently the study on these aspects has been vast (e.g. Ferreira et al. [7]; Montiel et al. [8]); however, it has been difficult to promote R\&D for many regions, such as Latin America, especially in Mexico, a country that requires a plan to generate innovative entrepreneurs [11]. For 
this reason, Latin American countries have sought to strengthen entrepreneurship education programs [14], especially within technology-related fields.

For this reason, the objective of this research was to evaluate whether the University Support and Teaching competencies affect the entrepreneurial competencies in software engineering and graphic design students. Through the sample of 201 students from a university in Northwest Mexico, it was possible to corroborate the three hypotheses raised. The results suggest that entrepreneurial training depends on both external aspects (university and teaching) and internal aspects (entrepreneurial competencies), where the university is seen as an open system [17], but also as a part of a wider system such as the triple helix, which shows that the joint work of academia, industry and government relations can generate innovation and development for society [10].

While the results shown cannot be generalized due to the type of used sampling (nonprobabilistic) -which is the main limitation of the study- through this research, it is proposed that the university in the region should adapt principles and experiences from the entrepreneurial university model [9-10] to its own reality, where financial and human resources are not optimal for training entrepreneurs. In this investigation, it could be observed that the efforts made by the university have favorably impacted on the development of entrepreneurial competencies of students. In this sense, for future research, it would be convenient to follow up on the present investigation; likewise, to involve other variables that could help to understand the emerging concept of the entrepreneurial university in the Mexican context within the technology and engineering field. Thus, the relevance of the traditional teaching method should be thoroughly reviewed in order to improve university entrepreneurial education [69-72].

\section{$6 \quad$ References}

[1] Fellnhofer, K. (2019). Toward a taxonomy of entrepreneurship education research literature: A bibliometric mapping and visualization. Educational Research Review, 27, 28-55. https://doi.org/10.1016/j.edurev.2018.10.002

[2] Kakouris, A. and Georgiadis, P. (2016). Analysing entrepreneurship education: a bibliometric survey pattern. Journal of Global Entrepreneurship Research, 6(6), 1-18. https://doi.org/10.1186/s40497-016-0046-y

[3] Skute, I. (2019). Opening the black box of academic entrepreneurship: a bibliometric analysis. Scientometrics, 120, 237-265. https://doi.org/10.1007/s11192-019-03116-w

[4] Skute, I., Zalewska-Kurek, K., Hatak, I. and de Weerd-Nederhof, P. (2019). Mapping the field: a bibliometric analysis of the literature on university-industry collaborations. The Journal of Technology Transfer, 44, 916-947. https://doi.org/10.1007/s10961-017-9637-1

[5] Schumpeter, J.A. (2003). Capitalism, Socialism \& Democracy. (5th ed.). USA: Taylor \& Francis.

[6] Drucker, P. (1985). Innovation and Entrepreneurship. Practices and Principles. New York: Harper \& Row.

[7] Ferreira, M., Reis, N.R. and Miranda, R. (2015). Thirty years of entrepreneurship research published in top journals: Analysis of citations, co-citations and themes. Journal of Global Entrepreneurship Research, 5(17), 2-22. https://doi.org/10.1186/s40497-015-0035-6

[8] Montiel, H., Solé, F. and Palma, Y. (2012). Mapping the intellectual structure of entrepreneurship research: revisiting the invisible college. RBGN-Revista Brasileira de Gestao de 
Paper-University Support, Teaching Competencies and Entrepreneurial Competencies in Software...

Negócios, 14(42), 41-58. Retrieved from: https://www.redalyc.org/pdf/947/94723262003. $\underline{\text { pdf }}$

[9] Etzkowitz, H., Webster, A., Gebhardt, C., and Terra, B.R.C. (2000). The future of the university and the university of the future: evolution of ivory tower to entrepreneurial paradigm. Research Policy, 29(2), 313-330. https://doi.org/10.1016/s0048-7333(99)00069-4

[10] Etzkowitz, H. A., and Leydesdorff, L. (Eds.). (1997). Universities and the Global Knowledge Economy: A Triple Helix of Academic-Industry-Government Relations. London: Cassell Academic.

[11] Global Entrepreneurship Monitor (GEM, 2018). Global Report 2017/18. Global Entrepreneurship Research Association (GERA). Retrieved from: https://www.gemconsortium.org/report/gem-2017-2018-global-report, https://doi.org/10.1093/acrefore/978019022 $\underline{4851.013 .156}$

[12] Lederman, D., Messina, J. Pienknagura, S. and Rigolini, J. (2014). El emprendimiento en América Latina: muchas empresas y poca innovación-Resumen [Entrepreneurship in Latin America: many companies and little innovation - Summary]. Washington, DC: Banco Mundial. https://doi.org/10.1596/978-1-4648-0284-3

[13] Vidal, R. (2008). Latinoamericanos: ¿Emprendedores competitivos? [Latin Americans: Competitive entrepreneurs?]. Journal of Globalization, Competitiveness \& Governability, 2(2), 126-139. https://doi.org/10.3232/GCG.2008.V2.N2.08 (In Spanish).

[14] Sánchez, J.C., Ward, A., Hernández, B. and Florez, J.L. (2017). Educación emprendedora: Estado del arte. [Entrepreneurial Education: State of the Art]. Propósitos y Representaciones, 5(2), 401-473. https://doi.org/10.20511/pyr2017.v5n2.190

[15] Gallegos, R., Grandet, C., and Ramírez, P. (2014). Los Emprendedores de TIC en México: Recomendaciones de política pública para su nacimiento, crecimiento y consolidación [ICT entrepreneurs in Mexico: public policy recommendations for their birth, growth and consolidation]. Instituto Mexicano para la Competitivdad (IMCO). Retrieved from: http:// imco.org.mx/wp-content/uploads/2014/05/20140507_Los_Emprendedores_de_TIC_en_ Mexico.pdf (In Spanish). https://doi.org/10.2307/j.ctv3f8q98.11

[16] Kantis, H., Federico, J. and Ibarra, S. (2014). Índice de Condiciones Sistémicas para el Emprendimiento Dinámico [ Index of Systemic Conditions for Dynamic Entrepreneurship A tool for action in Latin America]. Rafaela: Asociación Civil Red Pymes Mercosur. (In Spanish).

[17] Hernández, A., Jiménez, N. and Trocel, M. (2015). La universidad como sistema complejo y sus actores en la movilización del conocimiento a la sociedad. [The university as a complex system and its actors in the mobilization of knowledge to society]. Novum Scientiarum, 1(1), 80-94. Retrieved from: https://core.ac.uk/download/pdf/277658309.pdf (In Spanish).

[18] Rasmussen, E. and Wright M. (2015). How can universities facilitate academic spin-offs? An entrepreneurial competency perspective. The Journal of Technology Transfer, 40, 782799. https://doi.org/10.1007/s10961-014-9386-3

[19] Lüthje, C. and Franke, N. (2003). The 'making' of an entrepreneur: testing a model of entrepreneurial intent among engineering students at MIT. R\&D Management, 33(2), 135-147 https://doi.org/10.1111/1467-9310.00288

[20] Heinonen, J. and Hytti, U. (2010). Back to basics: the role of Teaching in developing the entrepreneurial University. The International Journal of Entrepreneurship and Innovation, 11(4), 283-292. https://doi.org/10.5367/ijei.2010.0006

[21] Peltonen, K. (2015). How can teachers' entrepreneurial competences be developed? A collaborative learning perspective. Education + Training, 57(5), 492-511. https://doi.org/10. $\underline{1108 / \text { et-03-2014-0033 }}$ 
Paper-University Support, Teaching Competencies and Entrepreneurial Competencies in Software...

[22] Klein, P.G. and Bullock, J.B. (2006). Can Entrepreneurship Be Taught? Journal of Agricultural and Applied Economics, 38(2), 429-439. https://doi.org/10.1017/S107407080002246X

[23] Gartner, W.B (1988). Who is an entrepreneur? Is the wrong question. Entrepreneurship Theory Practice, 13(4), 47-68. https://doi.org/10.1177/104225878901300406

[24] Ramoglou, S., Gartner, W.B. and Tsang, E.W.K. (2020). "Who is an entrepreneur?” is (still) the wrong question. Journal of Business Venturing Insights, 13. https://doi.org/10.1016/ j.jbvi.2020.e00168

[25] Islam, T. (2019). Cultivating Entrepreneurs: Role of the University environment, locus of control and self-efficacy. 3er World Conference on Technology, Innovation and Entrepreneurship (WOCTINE). Procedia Computer Science, 158, 642-647. https://doi.org/10.1016/ i.procs.2019.09.098

[26] Arafeh, L. (2016). An entrepreneurial key competencies' model. Journal of Innovation and Entrepreneurship, 5(26), 1-26. https://doi.org/10.1186/s13731-016-0048-6

[27] Robles, L. and Zárraga-Rodríguez, M. (2015). Key Competencies for Entrepreneurship. Procedia Economics and Finance, 23, 828-832. 2nd Global Conference on Business, Economics, Management and Tourism, 30-31 October 2014, Prague, Czech Republic. https://doi.org/10.1016/s2212-5671(15)00389-5

[28] Rasmussen, E., Mosey, S. and Wright, M. (2014). The influence of university departments on the evolution of entrepreneurial competencies in spin-off ventures. Research Policy 43(1), 92-106. https://doi.org/10.1016/j.respol.2013.06.007

[29] Centro Nacional de Evaluación para la Educación Superior ([CENEVAL], 2005). Boletín Ceneval [National Center for the Evaluation of Higher Education Bulletin], 14, Mexico. (In Spanish). https://doi.org/10.23936/ree.v7i9.15

[30] 2005 Guerrero, M., Urbano, D. and Gajón, E. (2020). Entrepreneurial university ecosystems and graduates' career patterns: do entrepreneurship education programmes and university business incubators matter? Journal of Management Development. https://doi.org/10.1108/ jmd-10-2019-0439

[31] Guerrero, M., Urbano, D. and Gajón, E. (2017). Higher education entrepreneurial ecosystems: exploring the role of business incubators in an emerging economy, International Review of Entrepreneurship, 15(2), 175-202.

[32] Guerrero, M., Urbano, D., Cunningham, J.A. and Gajon, E. (2018). Determinants of graduates' start-ups creation across a Multi-campus entrepreneurial University: the case of Monterrey Institute of Technology and Higher Education, Journal of Small Business Management, 56(1), 150-178. https://doi.org/10.1111/jsbm.12366

[33] Instituto Tecnológico de Sonora ([ITSON], 2016). Plan de Desarrollo Institucional. PDI 2016-2020 [Institutional Development Plan, IDP 2016-2020]. Retrieved from: https://www.itson.mx/micrositios/pdi2020/Documents/pdi-2017.pdf (In Spanish).

[34] Instituto Tecnológico de Sonora ([ITSON], 2020). Plan de Desarrollo Institucional. PDI 2020 [Institutional Development Plan, IDP 2020]. Available at: https://www.itson.mx/micrositios/pdi2020/Paginas/modelo-educativo.aspx (In Spanish).

[35] Instituto Tecnológico de Sonora ([ITSON], 2019). Resultados. Cuarto Informe General de Actividades (2018-2019) [Results. Fourth General Activity Report]. Dean: Dr. Javier José Vales García. Retrieved from: https://www.itson.mx/rector/Documents/resultados-cuartoinforme-general-de-actividades-2018-2019.pdf (In Spanish). https://doi.org/10.22201/fder. 24488933e.2020.276-2.75212

[36] Instituto Tecnológico de Sonora ([ITSON], 2013). Filosofía institucional [Institutional philosophy]. Retrieved from: https://www.itson.mx/universidad/Documents/filosofia_institucional_mision_vision_valores.pdf (In Spanish).

[37] McClelland, D. C. (1961). The Achieving Society. Princeton: Van Nostrand Company. 
Paper-University Support, Teaching Competencies and Entrepreneurial Competencies in Software...

[38] Clarysse, B., Tartari, V., Salter, A. (2011). The impact of entrepreneurial capacity, experience and organizational support on academic entrepreneurship. Research Policy, 40(8), 1084-1093. https://doi.org/10.1016/j.respol.2011.05.010

[39] Heinonen, J., and Akola, E. (2007). Entrepreneurship Training and Entrepreneurial Learning in Europe - Results from the ENTLEARN Project, TSE Entre, Turku School of Economics, Esa Print Oy, Tampere.

[40] Lazear, E.P. (2005). Entrepreneurship. Journal of Labor Economics, 23(4), 649-680. https://doi.org/10.1086/491605

[41] Duarte, T., and Ruiz, M. (2009). Emprendimiento, una opción para el desarrollo [Enterprising, An option to the Development]. Scientia et Technica, 15(23), 326-331. Retrieved from https://www.redalyc.org/pdf/849/84917310058.pdf (In Spanish).

[42] Tinoco, O. (2008). Medición de la capacidad emprendedora de ingresantes a la Facultad de Ingeniería de la UNMSM [Measurement of the entrepreneurial capacity of new students to the Faculty of Industry Engineering of the UNMSM]. Industrial Data, 11(2), 18-23. Retrieved from http://www.redalyc.org/articulo.oa?id=81619829003 (In Spanish). https://doi. org/10.15381/idata.v11i2.6046

[43] Asociación Americana de Psicología ([APA], 2010). Diccionario Conciso de Psicología. [Dictionary of Psychology]. Mexico: Manual Moderno. (In Spanish).

[44] Hatthakijphong, P. and Ting, H. (2019). Prioritizing successful entrepreneurial skills: An emphasis on the perspectives of entrepreneurs versus aspiring entrepreneurs. Thinking Skills and Creativity, 34. https://doi.org/10.1016/j.tsc.2019.100603

[45] D’Este, P., Mahdi, S., Neely, A. and Rentocchini, F. (2012). Inventors and entrepreneurs in academia: What types of skills and experience matter? Technovation 32(5), 293-303. https://doi.org/10.1016/j.technovation.2011.12.005

[46] Fernández, A.B. and Miñarro, P. (2019). Personal self-knowledge, A key factor for entrepreneurship in people with disabilities. Journal of Entrepreneurship Education, 22(2), 1-6.

[47] Chi-hsiang, C. (2015). Effects of shared vision and integrations on entrepreneurial Performance. Empirical analyses of 246 new Chinese ventures. Chinese Management Studies, 9(2), 150-175. https://doi.org/10.1108/cms-04-2013-0057

[48] Carrera, M.M., Partida, A. and Villarreal, L.A. (2016). Visión empresarial a través del espíritu emprendedor de los estudiantes que cursan la unidad de aprendizaje del ámbito empresarial en la UANL, FACPYA. [Business vision through its entrepreneurial spirit of the students who attend the Learning Unit of the business sector in the UANL, FACPYA]. Innovaciones de Negocios, 13(26), 299-316. Retrieved from: http://eprints.uanl.mx/ 12642/1/13.26\%20A7.pdf (In Spanish). https://doi.org/10.23913/ricea.v5i10.80

[49] Chang, W. and Chen, S. (2015). The impact of World Café on entrepreneurial strategic planning capability. Journal of Business Research, 68(6), 1283-1290. https://doi.org/10.1016/ j.jbusres.2014.11.020

[50] Zampetakisa, L., Kafetsios, K. and Moustakis, V. (2017). Using emotional persuasion for changing attitudes towards entrepreneurship: An interpersonal perspective. Journal of Business Venturing Insights, 7, 50-54. https://doi.org/10.1016/j.jbvi.2017.03.002

[51] Yarza, I. (2000). Historia de la Filosofía Antigua [History of Ancient Philosophy]. Pamplona: EUNSA. (In Spanish).

[52] Whetten, D.A. and Cameron, K.S. (2011). Desarrollo de habilidades directivas [Developing Management Skills] (8a ed). Mexico: Pearson. (In Spanish).

[53] Fells, (2000). Fayol stands the test of time. Journal of Management History, 6(8), 345-360. https://doi.org/10.1108/13552520010359379 
Paper-University Support, Teaching Competencies and Entrepreneurial Competencies in Software...

[54] Rasmussen, E. and Jarl, O. (2010). University capabilities in facilitating entrepreneurship: A longitudinal study of spin-off ventures at mid-range universities. Research Policy, 39(5), 602-612. https://doi.org/10.1016/j.respol.2010.02.002

[55] Fischer, B. Salati, G.H., and Rücker, P. (2019). Universities' institutional settings and academic entrepreneurship: Notes from a developing country. Technological Forecasting and Social Change, 147, 243-252. https://doi.org/10.1016/j.techfore.2019.07.009

[56] León, S., and Caldera, D. (2015). El papel de las universidades ante el desempleo juvenil. Algunas reflexiones de los programas de emprendimiento. XII Encuentro Participación de la mujer en la ciencia. (In Spanish). https://doi.org/10.2307/j.ctv8bt39d.12

[57] Adeyemo, S.A. (2009). Understanding and acquisition of entrepreneurial skills: a pedagogical Reorientation for classroom teacher in science education. Journal of Turkish Science Education (TUSED), 6(3), 57-65.

[58] Van Dam, K., Schipper, M. and Runhaar, P. (2010). Developing a competency-based framework for teachers' entrepreneurial behavior. Teaching and Teacher Education, 26(4), 965971. https://doi.org/10.1016/j.tate.2009.10.038

[59] Frese, M., and Gielnik, M.M. (2014), The psychology of entrepreneurship. Annual Review of Organizational Psychology and Organizational Behavior, 1, 413-438. https://doi.org/ 10.1146/annurev-orgpsych-031413-091326

[60] Hair, J. F., Black, W. C., Babin, B. J., and Anderson R. E. (2014). Multivariate Data Analysis. (7th ed). USA: Pearson Education Limited.

[61] Creswell, J.W. (2009). Research design: Qualitative, quantitative, and mixed methods approaches. (3erd ed.). Thousand Oaks, California, USA: SAGE Publications.

[62] Sapsford, R. (2006). In V. Jupp, The SAGE Dictionary of Social Research Methods. (pp. 3214-315). London: SAGE.

[63] Maxwell, C.S., Lu, J. and Bryant, D.A. (2020). The impact of teacher entrepreneurial behaviour: a timely investigation of an emerging phenomenon, Journal of Educational Administration. https://doi.org/10.1108/jea-08-2019-0140

[64] Ramos, S. (2001). El perfil del hombre y la cultura en México [The profile of man and culture in Mexico]. Mexico: Colección Austral. (In Spanish).

[65] Paz, O. (2004). El laberinto de la soledad, Postdata, Vuelta a El laberinto de la soledad [The labyrinth of solitude, The other Mexico, Return to the labyrinth of solitude] (3rd ed.). Mexico: Fondo de cultura Económica. (In Spanish). https://doi.org/10.3406/carav.1975.1997

[66] Rodríguez, M. y Ramírez, P. (2003). Psicología del mexicano en el trabajo. [Psychology of the Mexican at work] (2nd. ed.) Mexico: McGraw Hill. (In Spanish).

[67] Ibargüengoitia, J. (2019). Instrucciones para vivir en México [Instructions for living in Mexico]. Mexico: Planeta. (In Spanish).

[68] Hofstede, G., Hofstede, G.J. (2005). Cultures and Organizations: Software of the Mind, Revised and Expanded (2nd ed.). New York: McGraw-Hill.

[69] Olokundun, M., Love Moses, C., Iyiola, O., Ibidunni, S., Ogbari, M., Peter, F., and Borishade, T. (2018). The effect of non-traditional teaching methods in entrepreneurship education on student's entrepreneurial interest and business startups: A data article. Data in Brief, 19, 16-20. https://doi.org/10.1016/j.dib.2018.04.142

[70] Sang, D. and Lin, J. (2019). How does Entrepreneurial Education Influence the Entrepreneurial Intention of College Students: The Moderating and Mediating Effects of Entrepreneurial Alertness International Journal of Emerging Technologies in Learning, 14(8), 139154. https://doi.org/10.3991/ijet.v14i08.10408

[71] Ma, L., Lan, Z. and Tan, R. (2020). Influencing Factors of Innovation and Entrepreneurship Education Based on the Theory of Planned Behavior. International Journal of Emerging Technologies in Learning, 15(3), 190-206. https://doi.org/10.3991/ijet.v15i13.15345 
Paper-University Support, Teaching Competencies and Entrepreneurial Competencies in Software..

[72] Omotosho, A., Asani, E., Ayegba, P. and Ayoola, J. (2020). Impact of Agricultural Education on Students' Career Choice: A Survey. International Journal of Emerging Technologies in Learning, 15(3), 51-61. https://doi.org/10.3991/ijet.v15i03.11260

\section{$7 \quad$ Authors}

Oswaldo Alberto Madrid Moreno is a professor at the Department of Computing and Design of the Instituto Tecnológico de Sonora. Email: oswaldo.madrid@itson.edu.mx

Marco Alberto Núñez Ramírez is a professor at the Department of Management of the Instituto Tecnológico de Sonora. His research focuses on entrepreneurship, management and organizational behavior. Email: marco.nunez@itson.edu.mx

Article submitted 2020-07-28. Resubmitted 2020-10-30. Final acceptance 2020-11-01. Final version published as submitted by the authors. 